\title{
Identification of $f g r$ gene and preliminary evaluation for agronomic traits of pandan sticky rice variety (Oryza sativa L.)
}

\author{
Thu T. Nguyen, \& Toan D. Pham*
}

Research Institute for Biotechnology and Environment, Nong Lam University, Ho Chi Minh City, Vietnam

ARTICLE INFO
Research Paper
Received: November 23, 2017
Revised: May 30, 2018
Accepted: June 20, 2018
Keywords
Agronomic traits
ESP - IFAP primers
Fgr gene
Gel consistency
Pandan sticky rice
*Corresponding author
Pham Duc Toan
Email: phamductoan@hcmuaf.edu.vn

Cited as: Nguyen, T. T., \& Pham, T. D. (2019). Identification of $f g r$ gene and preliminary evaluation for agronomic traits of pandan sticky rice variety (Oryza sativa L.). The Journal of Agriculture and Development 18(2), 39-48.

\begin{abstract}
Rice (Oryza sativa L.) is the most important food crop in Vietnam particularly in the Mekong Delta. Screening of good quality and high yield rice varieties are needed for rice production in Vietnam. The purpose of this study was to use molecular techniques to identify $f g r$ gene and to evaluate preliminarily agronomic traits of pandan sticky rice variety. The results showed that this variety contained $f g r$ gene. The fragrant allele was amplified by ESP - IFAP primers with a product of $255 \mathrm{bp}$ in size. Similarly, evaluation of agronomic traits showed that the pandan sticky rice variety displayed many desirable characteristics such as plant height of $108 \mathrm{~cm}$, panicle length of $25.6 \mathrm{~cm}$, seed/panicle 135 , 100-grain weight $2.07 \mathrm{~g}$, pandan smell, level 2 of alkali digestion, gel consistency $93 \mathrm{~mm}$. These results were useful information and could be applied for improving and providing pandan sticky rice variety for rice production.
\end{abstract}




\section{Nhận dạng gene "fgr" quy định mùi thơm và đánh giá sơ bộ các đặc điểm nông học giống nếp dứa (Oryza sativa $\mathrm{L}$.)}

\section{Nguyễn Thị Thu \& Phạm Đức Toàn*}

Viện Nghiên Cứu Công Nghệ Sinh Học và Môi Trường, Trường Đại Học Nông Lâm TP. Hồ Chí Minh, TP. Hồ Chí Minh

\section{THÔNG TIN BÀI BÁO}

Bài báo khoa học

Ngày nhận: 23/11/2017

Ngày chỉnh sửa: $30 / 05 / 2018$

Ngày chấp nhận: 20/06/2018

Từ khóa

Đặc tính nông học

Độ trở hồ

Gene $f g r$

Nếp dứa

Primer ESP - IFAP

*Tác giả liên hệ

Phạm Đức Toàn

Email: phamductoan@hcmuaf.edu.vn

\section{TÓM TẮT}

Cây lúa (Oryza sativa L.) là cây lương thực quan trọng nhất ở Việt Nam, đặc biệt là ở Đồng bằng sông Cửu Long. Chọn lựa giống lúa có năng suất, chất lượng cao là cần thiết cho việc sản xuất lúa gạo ở Việt Nam. Mục tiêu của nghiên cứu này là ứng dụng kỹ thuật sinh học phân tử để nhận dạng gen quy định mùi thơm và đánh giá sơ bộ các tính trạng nông học của giống nếp dứa. Kết quả nghiên cứu cho thấy giống nếp dứa có mang gen quy định mùi thơm. Đoạn khuếch đại gene quy định mùi thơm thể hiện ở kích thước khoảng 255 bp với cặp primer ESP - IFAP. Tương tự, kết quả đánh giá các đặc tính nông học cho thấy giống nếp dứa có nhiều đặc tính mong muốn như chiều cao cây trung bình khoảng $108 \mathrm{~cm}$, chiều dài bông khoảng $25,6 \mathrm{~cm}$, số hạt trên bông là 135 hạt/bông, trọng lượng 100 hạt là $2,07 \mathrm{~g}$, hạt gạo thơm, có độ trở hồ cấp 2, độ bền thể gel cao khoảng $93 \mathrm{~mm}$, thuộc loại rất mềm. Kết quả này là những thông tin hữu ích góp phần vào việc cải tiến và cung cấp thêm giống nếp thơm trong sản xuất lúa.

\section{1. Đặt Vấn Đề}

Việt Nam là nước xuất khẩu gạo lớn thứ hai trên thế giới sau Thái Lan, tuy nhiên chất lượng gạo Việt Nam còn thấp nên giá gạo xuất khẩu chưa cao vì giá trị thương phẩm còn thấp. Nói chung, giá trị thương phẩm của gạo tùy thuộc vào thị hiếu và sở thích của người tiêu dùng. Thông thường người ta chú ý đến tŷ̉ lệ gạo nguyên, dạng hạt, độ trắng của gạo, màu sắc, trong đó các tố chất về hàm lượng amylose, độ mềm dẻo, độ trở hồ và mùi thơm của cơm là các yếu tố được người tiêu dùng quan tâm nhiều nhất. Trước đây, chọn giống theo phương pháp truyền thống dựa vào kiểu hình thế hệ con lai là chính sẽ mất nhiều thời gian và khó đánh giá một cách toàn diện do ảnh hưởng của yếu tố môi trường. Mùi thơm hạt gạo là tính trạng do một gene lặn kiểm soát, có kiểu hình rất phức tạp bởi nó phụ thuộc vào môi trường bên ngoài rất nhiều.
Hiện nay, với sự tiến bộ của công nghệ sinh học mà đặc biệt là sinh học phân tử, các chỉ thị phân tử đã được ứng dụng trong chọn lọc giống lúa để đánh dấu liên kết các gene có liên quan đến tính trạng mong muốn, do vậy dùng chỉ thị phân tử khẳng định lại đánh giá các tính trạng thông qua kiểu gene và không bị ảnh hưởng tác động điều kiện môi trường (Nguyen \& ctv., 2004). Những nghiên cứu về giống lúa kháng rầy nâu, bệnh đạo ôn, bệnh bạc lá đã được ứng dụng rất thành công trong chọn giống nhờ các dấu phân tử (Bui, 2002). Bên cạnh đó, việc ứng dụng phương pháp chỉ thị phân tử trong chọn các giống lúa dựa trên các tính trạng độ trở hồ, mùi thơm cho nhiều hiệu quả về kinh tế, và tính chính xác cao hơn các phương pháp thông thường khác.

Trong khuôn khổ của nghiên cứu này, việc ứng dụng kỹ thuật sinh học phân tử kết hợp với các đặc điểm hình thái, nông học sẽ đánh giá chi tiết hơn các đặc tính mong muốn của giống nếp dứa 
thơm, nhằm khẳng định giống đạt phẩm chất gạo tốt, từ đó sẽ giúp đáp ứng nhu cầu của người tiêu dùng trong nước và xuất khẩu.

\section{Vật Liệu và Phương Pháp Nghiên Cứu}

\subsection{Vật liệu nghiên cứu}

Vật liệu nghiên cứu là giống lúa nếp dứa thơm (Hình 1 và 2 ) được trồng và nhân giống trong nhà lưới của Viện Nghiên cứu Công nghệ Sinh học và Môi trường (RIBE), Trường Đại học Nông Lâm Thành phố Hồ Chí Minh. Các giống lúa Nàng thơm mùa, lúa cẩm, lúa nếp IR4625 và hai giống lúa hoang được thu thập tại quận 9, Thành phố Hồ Chí Minh cũng được sử dụng để thực hiện các thí nghiệm đánh giá phẩm chất hạt gạo.

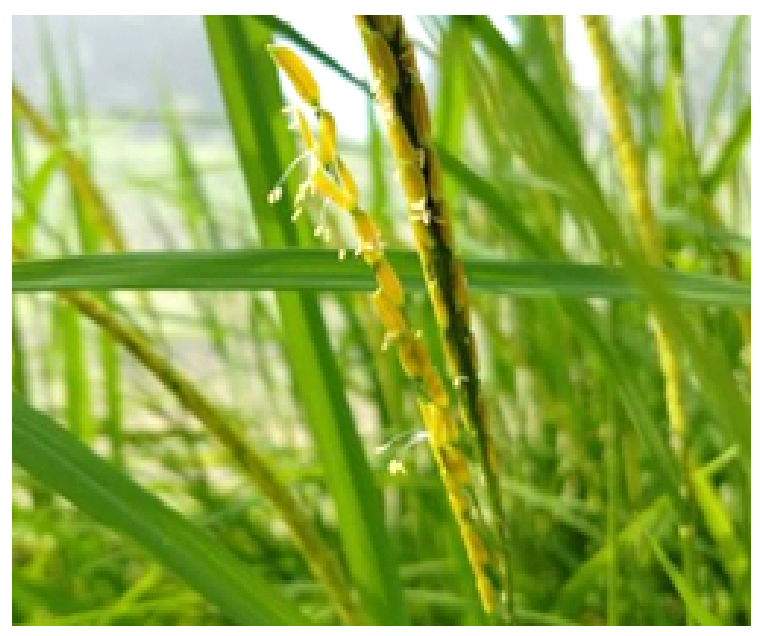

Hình 1. Lúa nếp dứa giai đoạn thụ phấn.

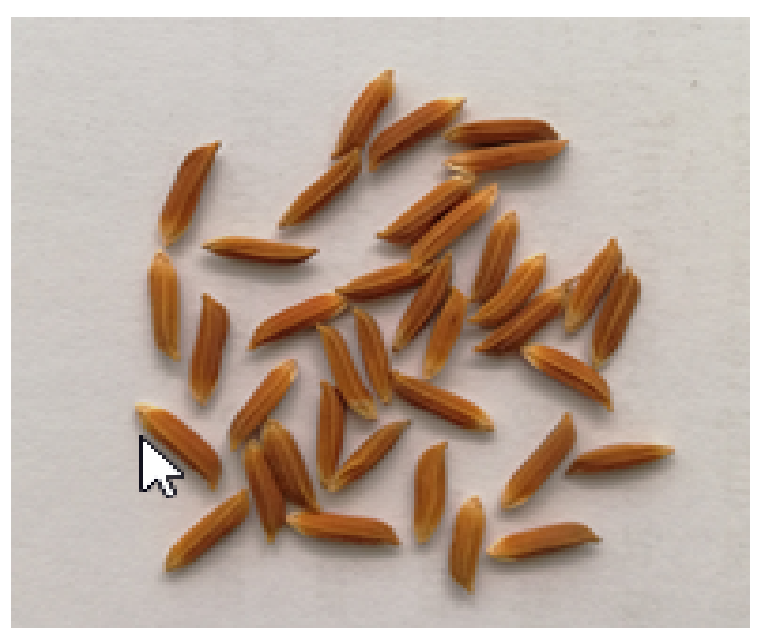

Hình 2. Hạt lúa nếp dứa sau thu hoạch.

\subsection{Phương pháp nghiên cứu}

\subsubsection{Nhận dạng gene fgr quy định tính thơm của giống lúa nếp dứa}

- Ly trích DNA:

Tổng số 400 cá thể nếp dứa được chọn ngẫu nhiên và ly trích DNA bằng quy trình ly trích DNA được cải tiến tại Viện Nghiên cứu Công nghệ Sinh học và Môi trường, Trường Đại học Nông Lâm TP.HCM.

- Quy trình phản ứng PCR:

Trình tự các cặp primer sử dụng trong phản ứng $\mathrm{PCR}$ và các thành phần trong một phản ứng đã tối ưu hóa được trình bày dưới Bảng 1 . Thành phần hóa chất của mỗi phản ứng $\mathrm{PCR}$ được thể hiện trong Bảng 2. Phản ứng PCR được thực hiện trên máy GeneAmp PCR Apply Biosystem 9700 Thermo Fisher Scientific, với chu trình nhiệt như sau: 1 chu kỳ ở $95^{\circ} \mathrm{C}$ trong thời gian 5 phút, 35 chu kỳ của $95^{\circ} \mathrm{C}$ trong thời gian 30 giây, $58^{\circ} \mathrm{C}$ trong thời gian 30 giây, $72^{0} \mathrm{C}$ trong thời gian 60 giây, và 1 chu kỳ ở $72^{0} \mathrm{C}$ trong 5 phút, cuối cùng là giữ ở $4^{0} \mathrm{C}$. Sản phẩm $\mathrm{PCR}$ được trộn với GelRedTM (Loading Buffer with TriColor) Bioline. Sau đó, điện di kiểm tra bằng gel agarose (Bioline) 1,5\% ở 80V, $400 \mathrm{~mA}$ trong thời gian 40 phút, và chụp ảnh dưới ánh sáng đèn UV.

\subsection{2. Đánh giá các đặc điểm hình thái nông học}

Các cá thể nếp dứa sau khi thực hiện kiểm tra sự hiện diện của gene quy định mùi thơm fgr sẽ được hỗn dòng, tiếp tục nhân giống tại nhà lưới và đánh giá các đặc tính nông học cơ bản. Các đặc điểm hình thái và nông học thực hiện trên 30 cá thể được lựa chọn ngẫu nhiên, các chỉ tiêu theo dõi bao gồm chiều cao cây và độ dày thân; chiều dài và chiều rộng phiến lá, lá đòng; chiều dài thoát cổ bông và chiều dài trục chính của bông; tổng số hạt/bông và tổng số hạt chắc trên bông, trong lượng 100 hạt; chiều dài và chiều rộng hạt lúa, hạt gạo.

\subsection{3. Đánh giá phẩm cấp hạt gạo}

Các cá thể nếp dứa nhân giống trong nhà lưới sau khi thu hoạch sẽ được hỗn dòng với nhau, lựa chọn ngẫu nhiên để đánh giá dựa theo tiêu chuẩn và thang đánh giá của Viện lúa quốc tế IRRI (Bảng 3 và 4). Mỗi thí nghiệm khảo sát được lặp lại 3 lần và lấy giá trị trung bình. 
Bảng 1. Trình tự các cặp primer dùng để nhận dạng gene "fgr"quy định mùi thơm trên cây lúa

\begin{tabular}{clc}
\hline STT & Trình tự $\left(5^{\prime}-3^{\prime}\right)$ & Kích thước (bp) \\
\hline \multirow{2}{*}{1} & $\begin{array}{l}\text { ESP: 5'-TTGTTTGGAGCTTGCTGATG-3' } \\
\end{array}$ & EAP: 5'-AGTGCTTTACAGCCCGC-3' \\
\hline \multirow{2}{*}{2} & $\begin{array}{l}\text { ESP: 5'-TTGTTTGGAGCTTGCTGATG-3' } \\
\text { IFAP: 5'-CATAGGAGCAGCTGAAATATATACC-3' }\end{array}$ & \multirow{2}{*}{255} \\
\hline \multirow{2}{*}{3} & $\begin{array}{l}\text { EAP: 5'-AGTGCTTTACAGCCCGC-3' } \\
\text { INSP: 5'-CTGGTAAAGTTTATGGCTTCA-3' }\end{array}$ & \multirow{2}{*}{355} \\
\hline
\end{tabular}

Nguồn: Bradbury \& ctv. (2005).

Bảng 2. Thành phần và thể tích các hóa chất dùng trong phản ứng $\mathrm{PCR}$

\begin{tabular}{lcc}
\hline Hóa chất & Thể tích phản ứng & Nồng độ phản ứng \\
\hline Master Mix $(2 \mathrm{X})$ & $6,5 \mu \mathrm{L}$ & $1 \mathrm{X}$ \\
Primer ESP $(10 \mu \mathrm{M})$ & $0,5 \mu \mathrm{L}$ & $1 \mu \mathrm{M}$ \\
Primer IFAP $(10 \mu \mathrm{M})$ & $0,5 \mu \mathrm{L}$ & $1 \mu \mathrm{M}$ \\
Primer INSP $(10 \mu \mathrm{M})$ & $0,5 \mu \mathrm{L}$ & $1 \mu \mathrm{M}$ \\
Primer EAP $(10 \mu \mathrm{M})$ & $0,5 \mu \mathrm{L}$ & $1 \mu \mathrm{M}$ \\
DNA mẫu & $1 \mu \mathrm{L}$ & \\
Nước khử ion & Thêm vừa đủ $12,5 \mu \mathrm{L}$ & \\
\hline
\end{tabular}

Bảng 3. Chỉ tiêu và cấp đánh giá đánh giá độ trở hồ

\begin{tabular}{cllc}
\hline STT & Độ phân huỷ của kiềm & Độ trải rộng của hạt gạo & Cấp đánh giá \\
\hline 1 & Thấp & Hạt gạo còn nguyên, không bị ảnh hưởng & 1 \\
2 & Thấp & Hạt gạo phồng lên & 2 \\
3 & Trung bình & Phồng lên, viền còn nguyên, nở ít & 3 \\
4 & Trung bình & Phồng lên, viền còn nguyên, nở rộng & 4 \\
5 & Trung bình & Hạt rã ra, viền hoàn toàn nở rộng & 5 \\
6 & Cao & Hạt tan ra hoàn toàn với viền & 6 \\
7 & Cao & Hạt tan ra hoàn toàn và trong & 7 \\
\hline
\end{tabular}

Bảng 4. Thang đánh giá độ bền thể gel của hạt gạo

\begin{tabular}{ccc}
\hline Cấp độ & $\begin{array}{c}\text { Chiều dài } \\
(\mathrm{mm})\end{array}$ & $\begin{array}{c}\text { Xếp loại độ bền } \\
\text { thể gel }\end{array}$ \\
\hline 1 & $81-100$ & Rất mềm \\
3 & $61-80$ & Mềm \\
5 & $41-60$ & Trung bình \\
7 & $35-40$ & Cứng \\
9 & $<35$ & Rất cứng \\
\hline
\end{tabular}

- Độ trở hồ theo phương pháp IRRI (1996): Chỉ tiêu và cấp đánh giá độ trở hồ được trình bày ở Bảng 3 .

- Đánh giá độ bền thể gel theo phương pháp của IRRI (1996): Độ bền thể gel là đặc tính góp phần xác định kết cấu của hạt cơm, trong nhóm gạo có cùng hàm lượng amylose, giống có độ bền gel mềm thì được ưa thích hơn vì cơm nấu lên sẽ mềm hơn (Nguyen, 2008).

\section{Kết Quả và Thảo Luận}

\subsection{Kết quả PCR nhận diện gene " $f g r "$ quy định mùi thơm trên giống lúa nếp dửa bằng sinh học phân tử}

Nghiên cứu này đã sử dụng tổ hợp primer ESP, IFAP, INSP và EAP để nhận diện gene " $f g r "$ quy định mùi thơm của giống nếp dứa. Kết quả điện di sản phẩm PCR với các primer ESP, IFAP, INSP và $\mathrm{EAP}$ trên gel agarose 1,5\%. Từ kết quả phân tích được thể hiện ở Hình 3 cho thấy, các giếng từ 2 - 16 đều xuất hiện 2 vạch DNA có kích thước khoảng $580 \mathrm{bp}$ và 255 bp còn giếng $17-19$ thì xuất hiện 2 band 580 bp và 355 bp. Vạch DNA 


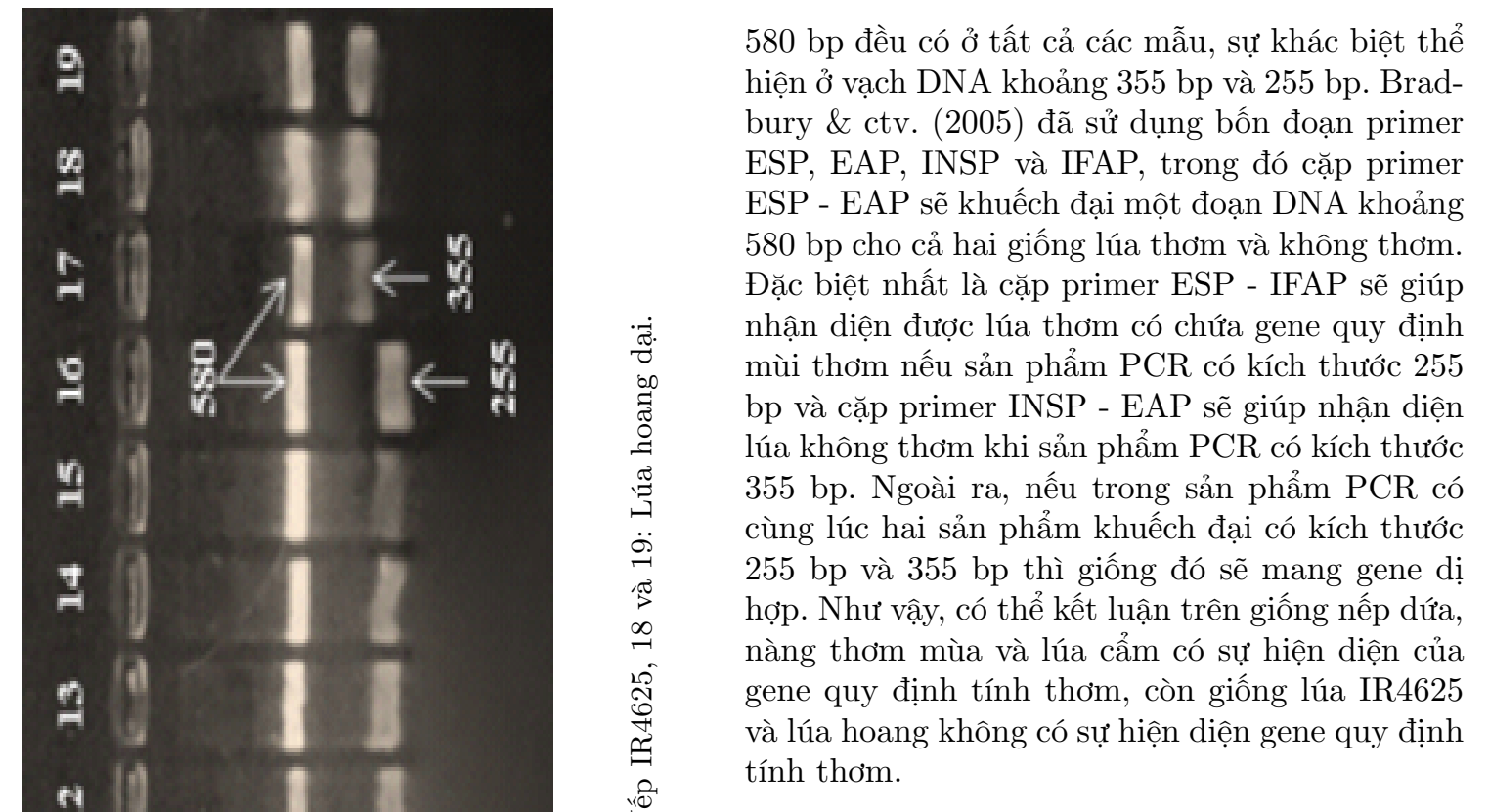

3.2. Kết quả đánh giá các đặc điểm nông học

Các chỉ tiêu nông học thực hiện đo đạc trên 30 cá thể được lựa chọn ngẫu nhiên, sau đó lấy giá trị trung bình và thu được kết quả các chỉ tiêu.

\subsubsection{Chỉ tiêu thân và lá đòng}

Đối với chỉ tiêu chiều cao cây, kết quả thu được cho thấy giống nếp dứa có chiều cao trung bình $107,9 \mathrm{~cm}$. Theo phân loại của IRRI (1996) thì chiều cao cây lúa được chia làm 3 nhóm: nhóm thấp cây có chiều cao cây dưới 90 cm, nhóm trung bình có chiều cao cây từ 90 - $130 \mathrm{~cm}$ và nhóm cao cây với chiều cao trên $130 \mathrm{~cm}$. Từ kết quả trên có thể xếp giống nếp dứa vào nhóm chiều cao trung bình. Chiều cao cây lúa là một chỉ tiêu hình thái có liên quan đến nhiều chỉ tiêu khác, đặc biệt là tính chống đổ, cây lúa có thân ngắn và cứng có khả năng kháng đổ tốt hơn (Jennings \& ctv., 1979). Từ đó cho thấy giống nếp dứa với chiều cao thuộc loại trung bình có khả năng chống đổ ngã khá tốt. Thân lúa dày đóng vai trò như nơi lưu trữ carbohydrate cho lúa năng suất cao; hơn thế nữa, các đặc điểm hình thái như độ dày lóng (thân), kích thước lá và chiều cao cây tại giai đoạn đầu được coi là đặc điểm quan trọng trong sản xuất lúa cao sản (Chen \& ctv., 2005; Hirose \& ctv., 2006). Kết quả đo được giá trị độ dày thân trung bình của giống nếp dứa là $5,8 \mathrm{~mm}$; chiều dài phiến lá trung bình là $76,9 \mathrm{~cm}$ và $13,6 \mathrm{~mm}$ là chiều rộng phiến lá trung bình (Bảng 5).

Lá đòng có vai trò quan trọng và liên quan 
mật thiết đến năng suất thông qua khối lượng hạt. Theo Yoshida (1981), diện tích lá đòng lớn sẽ có khả năng quang hợp và khả năng tích lũy chất khô cao dẫn đến việc dễ đạt năng suất cao. Độ dài lá đòng đo được biến động từ 28,5 - 54,0 $\mathrm{cm}$ và chiều rộng lá đòng từ $10-15 \mathrm{~mm}$ (Bảng $5)$.

\subsubsection{Chỉ tiêu bông lúa}

Độ hở cổ bông phụ thuộc vào đặc tính di truyền của giống, mặt khác còn chịu ảnh hưởng của điều kiện ngoại cảnh. Nếu điều kiện ngoại cảnh thích hợp thì bông lúa trổ thoát khỏi đòng, ngược lại nếu bị khô hạn hay gặp sâu bệnh hại tấn công vào giai đoạn trổ thì bông lúa sẽ bị trổ nghẹn ở cổ bông (Nguyen \& ctv., 1997). Qua theo dõi có thể thấy các cá thể giống nếp dứa trổ thoát cổ bông tốt, ở mức trung bình là $2,1 \mathrm{~cm}$; chiều dài trục chính dao động từ $21,7 \mathrm{~cm}$ đến $29,3 \mathrm{~cm}$, giá trị trung bình là 25,6 cm (Bảng 6).

\subsubsection{Năng suất và các yếu tố cấu thành năng suất}

Số hạt/bông và số hạt chắc/bông là hai yếu tố ảnh hưởng rất lớn tới năng suất lúa. Mặc dù số bông/bụi nhiều, mà tổng số hạt trên bông không cao và tỷ lệ hạt lép nhiều thì cũng làm giảm năng suất. Theo kết quả ghi nhận được thì tổng số hạt/bông biến thiên từ 101 - 164 hạt/bông và số hạt chắc/bông trung bình là 104 hạt/bông. Số hạt chắc trên bông là yếu tố quan trọng góp phần làm tăng hoặc giảm năng suất cây lúa. Các giống có số hạt chắc/bông cao sẽ có tiềm năng cho năng suất cao. Kết quả trọng lượng 100 hạt dao dộng từ $1,78-2,50 \mathrm{~g}$ và đạt giá trị trung bình là 2,07 g (Bảng 6).

\subsubsection{Hình thái hạt lúa, hạt gạo}

Nhu cầu về chất lượng gạo trên thị trường thế giới khác nhau. Chiều dài hạt gạo là thông số quan trọng để phân loại gạo xuất khẩu và phụ thuộc rất lớn vào thị hiếu tiêu dùng của từng quốc gia. Theo Jennings \& ctv. (1979) cho rằng sở thích chiều dài hạt gạo thay đổi rất lớn từ vùng này đến vùng khác. Ví dụ, thị trường Nhật yêu cầu gạo hạt tròn, amylose thấp, cơm dẻo, nhưng thị trường Thái Lan thích hạt gạo dài, hàm lượng amylose trung bình, cơm mềm nhưng không dính. Từ kết quả ghi nhận được thì độ dài hạt gạo của giống nếp dứa trung bình là $7,0 \mathrm{~mm}$, bề rộng hạt gạo là $2,0 \mathrm{~mm}$ và tỷ lệ $\mathrm{D} / \mathrm{R}$ là 3,5 . Theo tiêu chuẩn phân loại gạo của IRRI (1988) thì giống nếp dứa thuộc dạng hạt thon dài, hai yếu tố trên phù hợp với nhu cầu xuất khẩu, góp phần làm tăng giá trị thương phẩm cho hạt gạo (Bảng 7).

\subsection{Kết quả đánh giá phẩm cấp hạt gạo}

Độ bền thể gel và độ trở hồ: Kết quả giá trị độ bền thể gel trung bình ghi nhận được đối với giống nếp dứa là $93 \mathrm{~mm}$ (Hình $4 \mathrm{a}$ ) và các giống đối chứng gồm lúa cẩm, nếp IR4625 và giống lúa tròn lần lượt là $98 \mathrm{~mm}$ (Hình 4b), $99 \mathrm{~mm}$ (Hình $4 \mathrm{c})$ và $55 \mathrm{~mm}$ (Hình $4 \mathrm{~d}$ ) cho thấy gạo nếp dứa, nếp IR4625 và lúa cẩm thuộc loại có độ bền thể gel rất mềm nằm trong khoảng $81-100 \mathrm{~mm}$, riêng lúa tròn thuộc loại có độ bền thể gel trung bình, với giá trị trong khoảng $41-60 \mathrm{~mm}$. Vì vậy, khi nếp dứa được nấu lên hạt cơm sẽ rất mềm và dẽ nhai đó là đặc tính được nhiều người tiêu dùng ưa thích. Mẫu hạt gạo ngâm với dung dịch $\mathrm{KOH}$

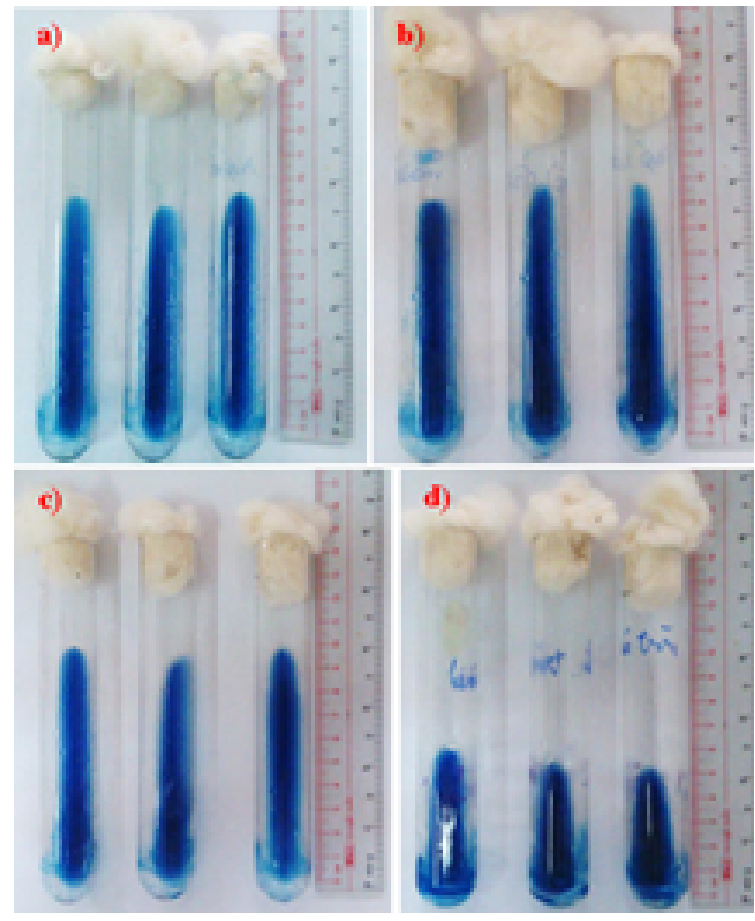

Hình 4. Kết quả phân tích độ bền thể gel của giống lúa nếp dứa và các giống đối chứng.

a) Nếp dứa b) Nếp cẩm c) IR4625 d) Lúa tròn.

1,7\% sau 23 giờ được đánh giá độ trở hồ theo phương pháp của IRRI (1996). Kết quả thu được cho thấy tất cả các mẫu hạt gạo nếp dứa đều phồng lên (Hình 5a) với kích thước lớn hơn rất nhiều so với hạt gạo không được ngâm với dung dịch $\mathrm{KOH}$ (Hình 5b). Dựa trên chỉ tiêu đánh giá, 
Bảng 5. Kết quả các chỉ tiêu thân và lá đòng

\begin{tabular}{|c|c|c|c|c|c|c|}
\hline Cá thể & $\begin{array}{l}\text { Chiều cao thân } \\
(\mathrm{cm})\end{array}$ & $\begin{array}{l}\text { Độ dày thân } \\
\text { (mm) }\end{array}$ & $\begin{array}{c}\text { Chiều dài } \\
\text { phiến lá } \\
\text { (cm) }\end{array}$ & $\begin{array}{c}\text { Chiều rộng } \\
\text { phiến lá } \\
(\mathrm{mm})\end{array}$ & $\begin{array}{l}\text { Chiều dài } \\
\text { lá đòng } \\
\text { (cm) }\end{array}$ & $\begin{array}{l}\text { Chiều rộng } \\
\text { lá đòng } \\
(\mathrm{mm})\end{array}$ \\
\hline 1 & 109,0 & 6,0 & 75,0 & 13,5 & 36,0 & 12,5 \\
\hline 2 & 118,0 & 6,0 & 84,0 & 13,0 & 47,0 & 13,0 \\
\hline 3 & 123,5 & 6,0 & 76,0 & 14,0 & 41,0 & 11,5 \\
\hline 4 & 105,0 & 5,0 & 75,2 & 14,5 & 32,5 & 13,0 \\
\hline 5 & 109,5 & 5,0 & 75,8 & 12,5 & 34,5 & 12,0 \\
\hline 6 & 107,0 & 4,5 & 79,5 & 14,0 & 38,0 & 13,5 \\
\hline 7 & 106,0 & 4,9 & 77,5 & 15,0 & 49,0 & 14,0 \\
\hline 8 & 110,0 & 6,2 & 74,2 & 13,5 & 37,0 & 11,0 \\
\hline 9 & 110,5 & 6,9 & 78,7 & 14,0 & 34,5 & 12,0 \\
\hline 10 & 104,0 & 7,3 & 77,1 & 13,0 & 47,5 & 13,5 \\
\hline 11 & 102,0 & 6,2 & 73,5 & 14,0 & 49,5 & 13,5 \\
\hline 12 & 110,0 & 6,0 & 81,2 & 13,5 & 41,0 & 12,5 \\
\hline 13 & 108,0 & 5,7 & 80,0 & 13,0 & 48,0 & 11,0 \\
\hline 14 & 100,0 & 6,4 & 74,9 & 13,0 & 49,5 & 13,0 \\
\hline 15 & 100,0 & 6,0 & 72,2 & 13,5 & 42,5 & 13,0 \\
\hline 16 & 105,0 & 5,3 & 75,0 & 13,0 & 38,0 & 13,0 \\
\hline 17 & 106,5 & 5,0 & 77,0 & 14,0 & 33,5 & 10,0 \\
\hline 18 & 107,0 & 6,1 & 72,5 & 14,5 & 45,5 & 13,5 \\
\hline 19 & 102,5 & 5,9 & 79,0 & 15,0 & 29,0 & 10,0 \\
\hline 20 & 100,0 & 6,1 & 73,0 & 12,5 & 49,0 & 12,5 \\
\hline 21 & 101,5 & 6,1 & 75,5 & 14,0 & 37,5 & 12,4 \\
\hline 22 & 106,0 & 5,9 & 74,5 & 13,0 & 43,5 & 13,0 \\
\hline 23 & 107,5 & 5,5 & 75,0 & 14,0 & 36,5 & 14,0 \\
\hline 24 & 107,0 & 5,0 & 74,8 & 12,5 & 28,5 & 12,0 \\
\hline 25 & 115,0 & 5,5 & 81,2 & 14,0 & 44,0 & 12,0 \\
\hline 26 & 113,0 & 5,3 & 78,9 & 14,0 & 52,5 & 13,0 \\
\hline 27 & 110,0 & 5,5 & 83,5 & 13,0 & 46,0 & 13,5 \\
\hline 28 & 108,0 & 6,5 & 73,6 & 14,0 & 49,5 & 15,0 \\
\hline 29 & 111,0 & 6,0 & 79,6 & 13,5 & 33,0 & 12,5 \\
\hline 30 & 114,0 & 7,0 & 78,2 & 13,0 & 54,0 & 14,5 \\
\hline Cao nhất & 123,5 & 7,3 & 84,0 & 15,0 & 54,0 & 15,0 \\
\hline Thấp nhất & 100,0 & 4,5 & 72,2 & 12,0 & 28,5 & 10,0 \\
\hline Trung bình & 107,9 & 5,8 & 76,9 & 13,6 & 41,6 & 12,7 \\
\hline
\end{tabular}


Bảng 6. Các chỉ tiêu bông lúa và năng suất

\begin{tabular}{|c|c|c|c|c|c|}
\hline Cá thể & $\begin{array}{c}\text { Chiều dài } \\
\text { thoát cổ bông } \\
(\mathrm{cm})\end{array}$ & $\begin{array}{l}\text { Chiều dài } \\
\text { của bông } \\
(\mathrm{cm})\end{array}$ & $\begin{array}{c}\text { Tổng số } \\
\text { hạt/bông } \\
\text { (hạt) }\end{array}$ & $\begin{array}{c}\text { Tổng số } \\
\text { hạt chắc/bông } \\
\text { (hạt) }\end{array}$ & $\begin{array}{c}\text { Trọng lượng } \\
100 \text { hạt } \\
\text { (g) }\end{array}$ \\
\hline 1 & 3,2 & 23,5 & 123 & 86 & 2,03 \\
\hline 2 & 1,8 & 23,0 & 134 & 102 & 1,97 \\
\hline 3 & 2,8 & 25,0 & 118 & 80 & 2,23 \\
\hline 4 & 2,6 & 25,2 & 106 & 83 & 2,19 \\
\hline 5 & 5,7 & 26,0 & 158 & 90 & 1,90 \\
\hline 6 & 1,6 & 27,3 & 130 & 103 & 2,25 \\
\hline 7 & 1,4 & 25,8 & 137 & 86 & 2,02 \\
\hline 8 & 1,4 & 27,1 & 118 & 90 & 1,98 \\
\hline 9 & 0,9 & 25,6 & 138 & 117 & 2,25 \\
\hline 10 & 3,6 & 27,2 & 140 & 103 & 1,86 \\
\hline 11 & 2,1 & 23,7 & 137 & 104 & 1,78 \\
\hline 12 & 2,2 & 28,4 & 151 & 109 & 2,05 \\
\hline 13 & 2,2 & 25,6 & 151 & 118 & 1,84 \\
\hline 14 & 1,1 & 25,5 & 128 & 103 & 2,25 \\
\hline 15 & 1,4 & 23,0 & 128 & 101 & 2,11 \\
\hline 16 & 1,9 & 21,7 & 127 & 102 & 2,50 \\
\hline 17 & 2,0 & 29,1 & 132 & 100 & 2,10 \\
\hline 18 & 1,6 & 27,0 & 150 & 120 & 2,12 \\
\hline 19 & 1,0 & 25,5 & 148 & 132 & 2,11 \\
\hline 20 & 1,5 & 27,0 & 101 & 94 & 1,99 \\
\hline 21 & 4,0 & 29,3 & 124 & 82 & 2,07 \\
\hline 22 & 1,5 & 23,7 & 120 & 77 & 2,01 \\
\hline 23 & 1,3 & 22,7 & 145 & 127 & 2,11 \\
\hline 24 & 1,7 & 24,5 & 134 & 102 & 2,12 \\
\hline 25 & 3,0 & 23,6 & 147 & 109 & 1,96 \\
\hline 26 & 3,2 & 25,4 & 132 & 92 & 2,07 \\
\hline 27 & 1,9 & 26,0 & 152 & 126 & 2,03 \\
\hline 28 & 1,9 & 24,5 & 164 & 144 & 2,10 \\
\hline 29 & 1,4 & 27,0 & 132 & 120 & 1,99 \\
\hline 30 & 1,5 & 28,5 & 140 & 115 & 2,14 \\
\hline Cao nhất & 5,7 & 29,3 & 101 & 77 & 1,78 \\
\hline Thấp nhất & 0,9 & 21,7 & 164 & 144 & 2,50 \\
\hline Trung bình & 2,1 & 25,6 & 135 & 104 & 2,07 \\
\hline
\end{tabular}


Bảng 7. Kích thước hạt lúa, hạt gạo

\begin{tabular}{|c|c|c|c|c|}
\hline STT & $\begin{array}{c}\text { Chiều dài } \\
\text { hạt lúa } \\
(\mathrm{mm})\end{array}$ & $\begin{array}{c}\text { Chiều rộng } \\
\text { hạt lúa } \\
\text { (mm) }\end{array}$ & $\begin{array}{c}\text { Chiều dài } \\
\text { hạt gạo } \\
(\mathrm{mm})\end{array}$ & $\begin{array}{c}\text { Chiều rộng } \\
\text { hạt gạo } \\
\text { (mm) }\end{array}$ \\
\hline 1 & 9,9 & 2,2 & 7,0 & 2,0 \\
\hline 2 & 10,0 & 2,2 & 7,2 & 2,0 \\
\hline 3 & 9,5 & 2,3 & 7,0 & 2,0 \\
\hline 4 & 9,4 & 2,5 & 6,9 & 2,0 \\
\hline 5 & 9,6 & 2,5 & 7,1 & 2,0 \\
\hline 6 & 10,0 & 2,9 & 7,2 & 2,1 \\
\hline 7 & 9,2 & 2,4 & 6,9 & 2,0 \\
\hline 8 & 9,4 & 2,1 & 6,9 & 2,0 \\
\hline 9 & 10,0 & 2,5 & 7,2 & 2,0 \\
\hline 10 & 9,5 & 2,5 & 7,0 & 2,1 \\
\hline 11 & 8,9 & 2,4 & 6,8 & 2,0 \\
\hline 12 & 9,2 & 2,5 & 7,2 & 2,0 \\
\hline 13 & 9,7 & 2,4 & 7,0 & 2,0 \\
\hline 14 & 10,0 & 2,2 & 7,1 & 2,0 \\
\hline 15 & 9,2 & 2,4 & 6,9 & 2,1 \\
\hline 16 & 9,6 & 2,6 & 7,0 & 2,0 \\
\hline 17 & 9,9 & 2,5 & 7,1 & 2,0 \\
\hline 18 & 9,8 & 2,6 & 6,9 & 2,1 \\
\hline 19 & 9,9 & 2,4 & 7,0 & 2,1 \\
\hline 20 & 10,0 & 2,6 & 6,9 & 2,0 \\
\hline 21 & 10,1 & 2,5 & 7,0 & 2,1 \\
\hline 22 & 9,0 & 2,3 & 6,5 & 2,0 \\
\hline 23 & 9,9 & 2,7 & 7,1 & 2,1 \\
\hline 24 & 9,9 & 2,6 & 7,1 & 2,1 \\
\hline 25 & 9,7 & 2,8 & 7,1 & 2,1 \\
\hline 26 & 9,2 & 2,4 & 6,9 & 2,0 \\
\hline 27 & 9,2 & 2,3 & 6,9 & 2,0 \\
\hline 28 & 9,1 & 2,6 & 6,8 & 2,1 \\
\hline 29 & 9,2 & 2,4 & 7,1 & 2,0 \\
\hline 30 & 9,6 & 2,6 & 7,0 & 2,0 \\
\hline Cao nhất & 10,1 & 2,9 & 7,2 & 2,1 \\
\hline Thấp nhất & 8,9 & 2,1 & 6,5 & 2,0 \\
\hline Trung bình & 9,6 & 2,5 & 7,0 & 2,0 \\
\hline
\end{tabular}




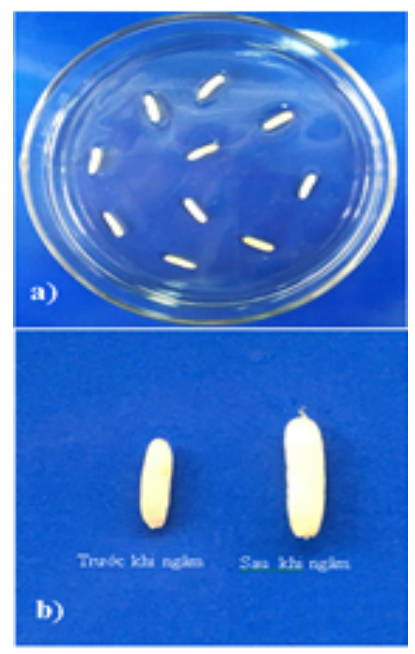

Hình 5. Hạt gạo nếp dứa sau khi thực hiện đánh giá độ trở hồ.

a) Hạt gạo nếp dứa sau 23 giờ trong dung dịch $\mathrm{KOH}$ $1,7 \%$.

b) Hạt gạo không được ngâm và hạt gạo sau ngâm.

từ đó kết luận rằng các mẫu này đều có độ trở hồ ở cấp độ 2.

\section{Kết Luận}

Qua đánh giá sơ bộ có thể nhận thấy giống lúa nếp dứa có tiềm năng và có các đặc tính mong muốn có khả năng đáp ứng cao cho nhu cầu phát triển giống và sản xuất lúa gạo hàng hoá trong tương lai. Giống có chiều cao cây trung bình khoảng $108 \mathrm{~cm}$, độ dày thân trung bình $5,8 \mathrm{~mm}$; chiều dài phiến lá trung bình $76,9 \mathrm{~cm}$ và chiều rộng phiến lá trung bình là $13,6 \mathrm{~mm}$; bông trổ thoát với độ dài là $2,1 \mathrm{~cm}$, chiều dài bông khoảng $25,6 \mathrm{~cm}$, số hạt trên bông là 135 hạt/bông, số hạt chắc là 104 hạt/bông, trọng lượng 100 hạt là 2,07 g. Hạt gạo thuộc dạng thon dài với tỉ lệ dài/rộng $>3$, hạt gạo có độ trở hồ cấp 2 , độ bền thể gel cao khoảng $93 \mathrm{~mm}$, thuộc loại rất mềm. Giống có mang gene " $f g r "$ quy định tính thơm, thực tế ngoài đồng ruộng cũng cảm nhận được mùi thơm.

\section{Tài Liệu Tham Khảo (References)}

Bradbury, L. M. T., Fitzgerald, T. L., Henry, R. J., Jin, Q., \& Waters, D. L. E. (2005). The gene for fragrance in rice. Plant Biotechnology Journal 3(3), 363-370.

Bui, B. C. (2002). Application of biotechnology techniques for seed selection, molecular markers in selecting varieties resistant to brown planthopper, anobium borer, blast and leaf blight disease. Final Research Report (71). Ho Chi Minh City, Vietnam: Ho Chi Minh City Department of Science and Technology.

Chen, Y. D., Wan, B. H., \& Zhang, X. (2005). Plant ideotype at heading for super high-yielding rice in doublecropping system in South China. Rice Science 12(2), 92-100.

Hirose, T., Ohdan, T., Nakamura, Y., \& Terao, T. (2006). Expression profiling of genes related to starch synthesis in rice leaf sheaths during the heading period. Physiologia Plantarum 128(3), 425-435.

IRRI (International Rice Research Institute). (1996). Standard evaluation system for rice testing program ( $4^{\text {th }}$ ed.). Manila, Philippines: IRRI.

IRRI (International Rice Research Institute). (1988). Standard evaluation system for rice testing program ( $3^{\text {rd }}$ ed.). Manila, Philippines: IRRI.

Jennings, P. R., Coffman, W. R., \& Kauffman, H. E. (1979). Rice improvement. Manila, Philippines: International Rice Research Institute.

Nguyen, T. H., Nguyen, G. D., Nguyen, H. T., \& Ha, V. C. (1997). Staple-foods crops-lecture notes volume I. Ha Noi, Vietnam: Agricultural Publishing House.

Nguyen D. N. (2008). Rice-lecture notes. Can Tho, Vietnam: Can Tho University.

Nguyen, L. T., Nguyen, T. T., Trinh, L. T., \& Bui, B. C. (2004). Application of molecular markers in rice breeding to create improved quality rice varieties with fragrance and intermediate amylose content. Final Research Report (2-44). Ha Noi, Vietnam: Ministry of Agriculture and Rural Development.

Yoshida S. (1981). Fundamentals of rice crop science. Manila, Philippines: International Rice Research Institute. 